\title{
Extensions of schooling environments into the local community, and social construction of democracy in Spain (1931-1939). Contributions made by the Freinet pedagogical movement
}

\author{
Extensiones comunitarias de la escuela y construcción social de la democracia en España \\ (1931-1939). Aportaciones del movimiento Freinet
}

Extensões comunitárias da escola e construção social da democracia na Espanha (1931-1939).

Contribuições do movimento Freinet

José Luis Hernández Huerta ${ }^{1}$

\begin{abstract}
This article highlights the social nature of the Freinet movement in Spain during the period of the Second Republic (1931-1936) and the Civil War (1936-1939), and investigates the community-based aspect of its schooling practices. To begin with, we examine a number of aspects of Spain's Freinet movement which help to see it as a social movement as well as a pedagogical one. Then, we study a) the main strategies employed by teachers to facilitate the social building of democracy through the schooling system, and b) the most significant extensions of the school into the local community, which helped break down the physical and symbolic barriers separating schooling institutions from the framework of ordinary citizens' daily existence.
\end{abstract}

Keywords: Freinet; Popular School; Spanish Second Republic.

\footnotetext{
${ }^{1}$ Ph.D. in Education from the University of Salamanca (Spain). Professor at the University of Valladolid (Spain). E-mail: jlhhuerta@mac.com
} 


\section{Resumen}

En este artículo se enfatiza el carácter social del movimiento Freinet español desarrollado durante la Segunda República (1931-1936) y la guerra civil (1936-1939) y se explora la dimensión comunitaria de sus prácticas escolares. En primer lugar, se analizan algunos aspectos de la organización freinetiana española que ayudan a pensarla como un movimiento social, además de pedagógico. En segundo lugar, se estudian, por un lado, las principales estrategias desplegadas por los maestros para posibilitar la construcción social de la democracia a través de la escuela y, por otro, las extensiones más significativas de ésta en la comunidad y que contribuyeron a erosionar las barreras físicas y simbólicas que separaban las instituciones escolares de la trama de la vida de los ciudadanos corrientes.

Palabras clave: Freinet; Escuela Popular; Segunda República española.

\section{Resumo}

Este artigo destaca o caráter social do movimento Freinet espanhol durante a Segunda República (1931-1936) e a Guerra Civil (1936-1939) e explora a dimensão comunitária das suas práticas escolares. Em primeiro lugar, são analisados alguns aspectos da organização freinetiana espanhola que ajudam a pensá-la como um movimento social, além de pedagógico. Em segundo lugar, estuda-se, por um lado, as principais estratégias utilizadas pelos professores para permitir a construção social da democracia por meio da escola e, por outro, as extensões mais significativas desta escola na comunidade e suas contribuições para derrubar as barreiras físicas e simbólicas que separavam as instituições escolares do cotidiano dos cidadãos comuns.

Palavras-chave: Freinet; Escola Popular; Segunda República Espanhola 


\section{Introduction}

Generally speaking, utopias can be thought of as the dreams of a future which is significantly different whilst still being familiar, and the strategies that a given society needs to implement in order to realise those dreams. In the arena of education, this idea has manifested itself, amongst other areas, around critical and emancipating schools of thought, with the utopia in question becoming something realistic and viable. Utopian pedagogical realism has developed a discourse which is both critical and possibilistic, considering education as an ingredient in the resistance to social reproduction and as a determining factor in bringing about social transformation. This implies that the utopia of education brings with it a certain attitude and a complex process aiming to bring about the dreamed future in the present, by means of education (Groves, 2014b). These ways of thinking fed into the discourses and practices of the New School and Progressive Education - international social and educational movements founded in the late $19^{\text {th }}$ and early $20^{\text {th }}$ Centuries, whose influences can still be felt today, with various mutations and adaptations. These movements brought together thinkers, intellectuals, white-collar workers and educators of varying types, with broad and diverse ideas and means of action, but sharing certain interests and motivations: to modernise the schooling system, and highlight the leading role that the school has to play in transforming the world into a more habitable, free, fair and supportive place.

Among these educational frontrunners were the schooling innovations and pedagogical proposals put forward by Célestin Freinet in the mid-1920s, which gave rise to an extensive international movement for innovative schooling and social change, known as the French "Modern School" (École Moderne). This movement, initially, arose as the result of the need to deal with the deplorable conditions faced by small rural schools in much of Europe: "overenrolled, poorly equipped, lacking any sort of material and any sort of comfort, eternally and tragically afflicted by social and economic oppression" (C. Freinet, 1936); the aim at that time was to create an authentic popular schooling system: democratic, lively, dynamic; linked in to the world around it; suited to the children's interests, abilities and needs; revivified and modernised through experimentation, the incorporation of scientific advances in the classroom, and a number of simple, economical and effective teaching techniques (free texts, the school printing press, national and international correspondence between schools, a cooperative school file, visits and school trips, etc.), capable, at the same time, of encouraging the building of a harmonious, balanced, democratic, egalitarian and peaceful society (González Monteagudo, 1988, 2013).

Cooperative working, understood as solidarity with one another's efforts and communication, was one of the pillars - perhaps the main one - upon which the activity of the Modern School was built. Little by little, teachers subscribing to Freinet's discipline came together and organised, like "sharpshooters, on the sidelines of orthodox teaching, working against the current, even clandestinely, to overhaul the institution of the village school" (E. Freinet, 1983). The results of these efforts manifested in various ways, including: the Coopérative de l'Enseignement Lä̈c (CEL - Cooperative for Secular Education), which later became the Institut Coopératif de l'École Moderne (ICEM - Cooperative Institute of the Modern School); the conferences organised by those organisations; and various publications (L'imprimerie à l'École, l'Éducateur Prolétarien, l'Éducateur, La Gerbe, coorevue d'enfants). Internationalisation was another of the distinctive traits of the group of Freinet's followers. In 1928, the founder of the Modern School was convinced that the building of the popular schooling system he envisaged would require a "decidedly international" effort, as education could "know no borders"; with that in mind, it would be crucial to "tear down all the barriers which languages represent between teachers and the general populace" (E. Freinet, 1983). Thus, gradually, from the late 1920s until the start of WWII, the pedagogical innovations of the 
French educator, the teachers' organisation he had created, and the wider movement which sustained it grew beyond the borders of France, becoming a global phenomenon; experiments in the Freinet vein were to be found in over thirty countries: Algeria, Argentina, Belgium, Bulgaria, China, Denmark, East Africa, French East Africa, French West Africa, Germany, Hungary, Italy, Japan Martinique, Mexico, Morocco, the Netherlands, Norway, Poland, Portugal, Romania, the Soviet Union, Spain, Sweden, Switzerland, Tonkin, Tunisia, the United Kingdom, Uruguay, the USA and Yugoslavia (Portier, 2014).

Spain, from the very beginning, was a hotbed for the Freinet movement on the international stage. In the late 1920s came the first rumblings of the school printing press, though it was the winds of educational modernisation brought by the Second Republic (19311936) which facilitated the development of a relatively large movement of teachers subscribing to Freinet's ideas, organised in the form of the Cooperativa española de la Técnica Freinet (CETF - Spanish Cooperative of Freinet Techniques), which managed to overhaul the principles, means and ends of primary schooling, vivify the rhythms and styles and of primary education, and extend the social domains in which it acted. However, this initiative ended with the end of the Civil War (1936-1939) and the establishment of the dictatorship headed by General Franco, which imposed a model of teaching wherein the most advanced and

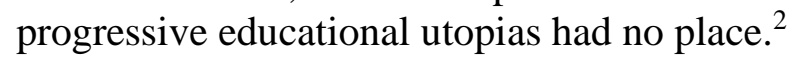

This article emphasises the social nature of the Spanish Freinet movement between the two World Wars, and explores the community aspect of its schooling practices. Firstly, we analyse various aspects of the origin and development of the Spanish Freinet movement, which will help readers to see it as a social movement as well as a pedagogical one. ${ }^{3}$ Secondly, we study the main strategies employed by these teachers to encourage the social construction of democracy through the schooling system, and also the most significant extensions of the school into the local communities, which helped break down the physical and symbolic barriers between schools and the daily lives of citizens, turning the schools into socio-cultural focal points for their local communities. ${ }^{4}$

The sources used for this investigation were printed materials and archives. Of the first category, of particular note are the Revista de Pedagogía (Pedagogical journal), one of the foremost specialist publications at the time, and the newsletter Colaboración, la Imprenta en la Escuela (Collaboration: School Printing Press), which was the official mouthpiece of the CETF. The archival sources, for their part, comprise 195 issues, belonging to 53 different collections, of children's school portfolios or workbooks created by the writing of free texts and school printing presses, held at various archives in Spain. ${ }^{5}$

\footnotetext{
${ }^{2}$ A literature review and critical state of the art about the influence and reception of Freinet in Spain during the Second Republic and the long years of the Transition to democracy can be found in Hernández Huerta (2017). Recently, a number of other relevant works have been published: Cid Fernández, Carrera Fernández, Diéguez Sans, and Cid Rodríguez (2017); Ferraz Lorenzo (2017); Groves (2017); Jaume i Campaner (2017); Jiménez Mier y Terán (2017); Ramos (2017); Sala Sureda and Vilaplana (2017); and Zurriaga i Agustí (2017).

${ }^{3}$ Groundbreaking work on this avenue of investigation, though focusing on the second stage of the Freinet movement, has been done by Tamar Groves (2002, 2009, 2010, 2012, 2014a, 2014b, 2017).

${ }^{4}$ The term "extensions" of the school refers, firstly, to an elementary and extended version of the schooling system, as a social projection of the school and the expansion of its space and time beyond the four walls of the classroom; secondly, the term relates to the metaphor coined by McLuhan (1996), to those primarily technological elements - in this case, the school printing press - that were initially alien to something (the schooling system), which gradually came to form part of the very fabric of that thing, affecting its view of itself, and establishing new relationships and synergies with the rest of the elements with which it interacted.

${ }^{5}$ The titles of the newspaper collections consulted for this work are: Actividad escolar; Alborada (Montijo); Avant; Baixeras; Caricia; Chicos; Claror; Consell; Del Vallés; Despertar; El carol; El conte del nen petit; El libro de los escolares de Plasencia del Monte; El nene (Barcelona); El pájaro azul; Endavant!; Esclat; Escolar almazorense; Estimul; Floreal; Garbí; Germanor; Helios; Ibèria; Ideas y Hechos; Inquietud; L'afany; L'alegria d'oló; L'espiga; La font; Llavor; Llum!; Mainada (Barcelona); Niños, pájaros y flores; Nuestras cosas; Petits;
} 


\section{The origin of a social and educational movement in Spain between the First and Second World Wars}

In the late 1920s, Spain received the first news of the innovative schooling techniques which Célestin Freinet was trialling in his school, and of the group of French teachers who were already adherents to those ideas, and beginning to weave together networks of communication and collaboration. They did so hand in hand with young and active teachers who, between 1926 and 1928, had received some type of aid or grant, either from the Administración Central, or from the Junta para la Ampliación de Estudios e Investigaciones Científicas (JAE - Further Scientific Research Council), which gave them the opportunity to make direct contact with the French pedagogue, observe his work with the school printing press and obtain some materials and a few publications, sufficient to begin experimenting in their own classes. Only a few months later, the Revista de Pedagogía published two articles by Madrid-based teacher Manuel Juan Cluet (Cluet, 1929a, 1929b) and, in the province of Lérida, thanks to the activities of Jesús Sanz, a teacher trainer, and Herminio Almendros, a primary school inspector, the first organised chapter of the Freinet movement began to operate, set up by Patricio Redondo and José de Tapia. All of these figures turned out, later on, to be charismatic, symbolic leaders, who were distinguished by their tireless work of dissemination, the exemplary school practices developed, the improvements they made to Freinet's own techniques, and the fact that they organised the Freinet movement in Spain (Hernández Huerta, 2012a).

The initial reception of the French educator's ideas and practices was made easier by two things. First of all, they were easily accepted by an increasingly broad frame of thought amongst teachers, aware of the technical and material modernisation of primary schooling, promoted by the specialist pedagogical press - in particular, by the Revista de Pedagogía mentioned earlier, which became the most representative means of accessing the educational issues that were being debated in Europe and America at the time. Secondly, their reception was facilitated by the fact that, at that time, Spain already had a relatively long tradition of innovative, forward-looking educational experiments, mainly concentrated in Madrid and Catalonia, backed mainly by progressive, liberal and secular groups, such as regenerationist, socialist, anarchist ideas and practices, certain versions of the New School and independent groups advocating pedagogical innovation (Escolano Benito, 2002; Hernández Díaz, 2008; Pozo Andrés, 2003; Viñao Frago, 2007).

Nonetheless, the wide dissemination and genuine expansion of Freinet culture in school and of the social transformation drive which fed it did not come about until 1933, when the original small cell swelled to over 60 teachers (Hernández Huerta \& Hernández Díaz, 2012). A key role in this expansion was played by the earliest indications of the Second Republic's educational policy, the pedagogical innovation group Batec and, once again, the Revista de Pedagogía. The regime established by the proclamation of 14 April 1931 paid special attention to primary schooling, helping to modernise it, instil a democratic system in it and extend it to full schooling; it improved the quality of initial teacher training and raised teachers' salaries, assigning the institution a central role in consolidating the Republic and building a freer, more diverse, fairer and more supportive society - values manifested by measures such as

Petits olotins; Renacer (Barcelona); Renacer (Mallorca); Revista escolar; Salut (Santa Fe del Montseny); Salut (Villanueva y Geltrú); Sembra; Sembra. Conte per a infants; Sembra. Quadern escolar de lectura; Serenor; Tibidabo; Trabajos escolares vividos; Treball; Vida escolar; Vida hurdana; Vida infantil (Aviá); Vida infantil (Jijona); Vilabesos; Vives; Voluntad. The issues consulted are housed in various archives across Spain: Fundación Enric Soler i Godes (Castellón), Archivo General de la Administración Civil del Estado (Alcalá de Henares), Archivo Histórico de la Ciudad de Barcelona (Barcelona), Archivo Personal de Antonio Solans Brandi (Barbastro, Huesca), Archivo Personal de José Vargas Gómez (Murcia), Archivo de la Universidad Jaume I. Fondo Fundación Enric Soler i Godes (Castellón), Biblioteca Rosa Sensat. Fons Històric (Barcelona). 
coeducation and bilingualism (Pérez Galán, 2011). For their part, the group Batec, an organisation of teachers "very scholarly in nature, without pre-set norms governing its development" (Benaiges Nogués, 1935b), which had been operating in Lérida for several years at that point, was crucial in the development of the Freinet network in Spain. It was from their ranks that the first adherents of the pedagogical techniques imported from France emerged (Redondo and Tapia among them), and it was one of the main points at which the members of the Freinet movement originated: around a third of those members had already been part of Batec (Jiménez Mier y Terán, 2007a). Apart from its sheer numbers, this was especially significant in that these teachers brought with them customs of communication and collaboration, experiences of participative democracy, the skills to organise and galvanise meeting, and strategies of negotiating with various local social, political and cultural actors. Revista de Pedagogía - and the publishing project to which it was attached - was crucially important in popularising the school printing press. Between 1930 and 1933, Batec facilitated the publication of a series of articles which set out the ideas initially put forward, introduced technical changes and offered broad reflections on the pedagogical extensions of technological innovation (Almendros, 1932a, 1932b, 1932c, 1933; Cluet, 1933). It was also responsible for the publishing of the book be Herminio Almendros, La Imprenta en la Escuela. La técnica Freinet, released in 1932 in the series "La Nueva Educación", consisting of a summary - with social and cultural background - of the pedagogical thinking thus far developed by the French educator, and a technical guide so that interested teachers could, from the start and under their own steam, work with the techniques of France's École Moderne (Almendros, 1932d).

The effect of the publication of La imprenta en la escuela soon became apparent amongst the community of primary school teachers. During the three years following the book's publication, the number of subscribers to Freinet's ideas grew exponentially, from little more than 20 in 1932 to nearly 200 in 1935, and the areas of Freinet's influence, which had so far been limited to Madrid and, mainly, to Lérida, extended to other provinces within Spain primarily to Barcelona, Valencia and Huesca, but also to other places further afield from the initial focal points of irradiation, such as Mallorca, Cáceres, Badajoz, Soria and Burgos (Hernández Huerta \& Hernández Díaz, 2012). The Modern School's ideas were particularly well received in rural communities, many of them isolated and socially, culturally and economically impoverished, having schools run "in tumbledown buildings, lacking material, with no resources other than the willingness of the children and their teachers" (Bover Oliveras, 1935), who, for their part, had only very scant initial training with notable lacunas, including vital experiences of personal growth and development in similar environments (Hernández Huerta, 2012a).

From the very beginning, the members of the Freinet group began to work together and relate to one another with the guiding principles of communication, collaboration and cooperation. Initially, the networks - diffuse, fragmented and short-reaching - were established by means of informal strategies of direct interpersonal support, working in small groups connected by short and sporadic meetings between teachers in the same area or from adjoining territories, and ordinary personal postal correspondence or using the communication established by inter-school exchanges of printed texts. These lively, dynamic and spontaneous approaches were those adopted by the majority (64\%) of members of the movement until the end of the Civil War, forming a sort of archipelago of island-schools connected by various types of correspondence - particularly school correspondence. However, in 1933, the movement began heading in a different direction, marking the start of a phase of institutionalisation. That year, a group of teachers, led by the pioneers, the main propagandists and the main experimenters with novel schooling techniques, with the approval of Freinet himself, took the initiative to join the movement together into a contiguous whole. This process was made easier by having Freinet's approval, and by the experience that some of the operatives had of taking 
part in trade-union groups, political parties or pedagogical innovation groups - Batec being particularly notable amongst these - and actively collaborating with popular education initiatives, such as the Misiones Pedagógicas. Thus, following in the footsteps of the French group, they opted for an associative model which resulted in the forming of the CETF, whose aims dealt with aspects linked to the dissemination of the ideas and materials of the ideas of the École Moderne and the group's financial survival:

1. To acquire, produce and circulate any and all material needed for the development of Freinet techniques or the school printing press; 2. To take action near to homes and builders and suppliers in order to obtain the materials; 3. To facilitate the members' acquisition of the typographic and auxiliary materials they need; and 4. To accumulate reserve funds and any contributions which can be gained, to construct an indivisible collective capital fund to be used for the spreading of the school printing press and of any organisation deemed useful to the development of the cooperative (Jiménez Mier y Terán, 2012).

The cooperative's internal dynamics were managed by various mechanisms of democratic participation and varied means of collective negotiation in the making of decisions affecting all or part of the community (Redacción, 1935d, 1936e). These processes took place directly during the general assemblies, which were held annually, where the members put forward their projects, deliberated as to the relevance, suitability and viability of those projects, and agreed on means of action pertinent to the group's principles, means and ends. The salient activities emerging from these agreements were channelled through working groups with clear objectives, defined responsibilities and a high degree of autonomy which, nevertheless, worked in collaboration with one another and in communication with the steering committee and, as far as possible, with the rest of the group as well. For its part, the steering committee was made up of an administrative council, a financial committee, a publications committee and a number of technical advisers (Cozcolluela, 1935). In addition to being the legal representation of the society, this committee had the responsibility of ensuring that it was run smoothly - amongst other things, coordinating tasks, ensuring that the agreements adopted at the general assemblies were enacted, lending dynamism to life within the organisation and extending the social reach of the movement. ${ }^{6}$ At these assemblies, decisions were made on essential aspects of the CETF's activity, such as the place, date and tea mini charge of organising its annual conferences, entitled Congreso de la Imprenta en la Escuela (Conference on the School Printing Press), the publication of the journal Colaboración, la Imprenta en la Escuela, the implementation of the general school file, the establishment of a collection of books written by children for others like them, called Lo que escriben los niños (What children write), the regulating of inter-school correspondence, and the translation, publication and distribution of Freinet's book, L'Imprimerie à l'école.

The journal Colaboración was one of the CETF's most successful projects. It was written by teachers "from within the school itself, at the crossroads of the daily journey, dealing with the actual reality of life in school, rather than the ideal schooling environment which so many imagine" (Redacción, 1935e). The pages of Colaboración reflected the

\footnotetext{
${ }^{6}$ An example of this may be found in the lectures which Freinet gave as part of the Escuela de Verano de la Normal de la Generalidad de Cataluña (Teacher Training Summer School, Catalonia Teacher Training College, Barcelona, 1933), participation in the Semana Pedagógica de Villafranca del Penedés (Education Week, Barcelona, 1935) and the Escuela de Verano de la Normal de la Generalidad de Cataluña organised by the CTFE (Barcelona, 1935).
} 
activities of the cooperative, the services it offered, the names of partners, schools sympathetic to the cause, published libros de vida, accounts of experiences with free texts, printing presses and linoleum etching, discussions on an enormously broad range of subjects, and technical innovations having emerged from the thinking behind those discussions (Jiménez Mier y Terán, 1996). Yet the publication was more than an internal communication device, a means of conveying interesting information or a tool for publicity and external dissemination. Firstly, it lent the group cohesion, creating a shared pedagogical outlook, and with it, a new alternative collective identity. To a large extent, the group's identity remained defined by the ways in which its members interacted, the professional and experimental consideration of its activity, the drive to modernise the primary schooling system, the members' aspirations of bringing about social change and the markedly popular character with which the movement was imbued from the very start, and which affected the way in which its members viewed themselves and viewed the schooling system, amongst other ways, emphasising and growing its projection in the community.

Secondly, the journal was set up as a symbolic arena for public debate about certain issues about which there was no clear shared opinion. Especially suggestive in this respect was the discussion of the type and degree of regulation of the school correspondence system backed by the CETF - an issue that was also touched upon in the general assembly, when the members, democratically and with various arguments available to them, settled the matter (Almendros, 1936; Benaiges Nogués, 1935b; Redacción, 1935c). This debate went beyond the technical, organisational and pedagogical aspects. The discussion revealed the still-enduring informal, spontaneous, intuitive and casual styles acquired by some teachers in the early stages of the movement or when they first came into contact with it, which contrasted with the new necessity of giving themselves standards to articulate, in a clear and ordered fashion, some basic aspects of the activity they all shared. It was a concrete example of a wider dilemma, which affected the very substance of the CETF: the crux of the issue related to the types and means of interaction that should take place within the group, oscillating between centralised and decentralised forms of organisation, between greater regulation and a greater degree of selfregulation - ultimately, between security and liberty.

The conferences organised, for their part, were especially transcendent events for the development of the Freinet organisation and for the wider movement which fed into that organisation. In total, there were two held: one in Lérida (July 1934) (Bover Oliveras, 1935) and another in Huesca (July 1935) (Cozcolluela, 1935; Redacción, 1935a, 1935b, 1935f), and a third was planned for Manresa (July 1936) (Redacción, 1936a, 1936b, 1936c). They took place over two or three consecutive days of intense work, and were the concrete result of a lengthy and laborious process, begun months earlier, which required large amounts of time and energy from the teachers, as well as considerable efforts for cooperation, collaboration and communication amongst themselves and with other educational groups, private entities and public institutions. From this standpoint, we can hold up three particularly noteworthy examples. Firstly, to make it easier for the members and activists to attend the conferences, connections were established with the national railway network, resulting in substantial discounts (up to $40 \%$ ) on return tickets, whatever the point of origin. Secondly, the sites chosen to host the gatherings were the buildings of the provincial teacher training colleges, which, for a few days, had their premises utterly transformed by exhibitions of children's workbooks, printed texts and other working materials, to be seen by visitors from various regions of Spain and, according to some testimonials, from France as well, and by demonstrations of how to work with the printing press, which gave the premises the feeling of a technical/pedagogical experimentation lab. Thirdly, given that it was expected - and indeed happened - that the conferences would be attended by partners, members of the movement not having joined the organisation, interested teachers outside of the organisation and representatives of the French 
parent group, additional communication strategies had to be used, beyond the messages disseminated by the journal, though that was the medium which carried the key information relating to the logistical side of the conferences.

These events were propitious for the exchange of experiences, concerns and technical advances relating to the school printing press, and represented obvious opportunities to fulfil the statutory mandate to hold an annual general meeting, ensuring a high level of attendance from stakeholders, but not only for this purpose. They represented opportunities for some visiting teachers to get away from the physical and intellectual isolation they endured in their day-to-day lives, and for the locals to escape their routines and their normal social, cultural and pedagogical stimuli; the events were also opportunities to establish new channels of professional cooperation and extend the international networks of collaboration built by the CETF. They also became forums for discussing the social role of schooling and of teachers, which, much like the journal, made a notable contribution to the building of that alternative collective identity and, through a range of forms of direct interpersonal relations, to the cohesion of the movement, reinforcing the sense of belonging to a group, increasing the sensation of reality of that group, and helping to create an atmosphere of "fraternal camaraderie" (Bover Oliveras, 1935). Ultimately, they were times and places which allowed the expression of the multiple facets coexisting within the movement, and experiencing a type of democracy based on direct participation and horizontal, equal-to-equal (rather than topdown) relations, which represented one more form of social construction of democracy.

The outbreak of the Civil War also marked the start of the disintegration of the CETF. The conference in Manresa was impeded, as was the distribution of the translated version of Freinet's book, and the most ambitious initiatives, such as the journal and the general school file, which required constant collaboration and fluid communications, were immediately paralysed. From that point onwards, the teachers in the Republican-held zone who were able to continue working with the school printing press had to begin meeting in the same old informal, spontaneous, intuitive and casual ways that were used at the start of the movement. Nevertheless, the Civil War witness the development of two of the most significant experiments: the Freinet School in Tibidabo - the first official Freinet school in the world outside of France - and the permanent school colony known as the República Infantil (Children's Republic) in Martorelles. Both were made possible by the negotiations carried out by the surviving leaders of the CETF with the City Council of Barcelona, which was the public administration which approved and backed them.

In the aftermath of the Civil War, 36\% of Freinet's disciples in Spain were subjected to administrative sanctions, with permanent expulsion from the teaching body and lowering of status. $6 \%$ were stripped of their licences to hold positions of responsibility in the public administration, as they were considered untrustworthy by Franco's regime. 25\% were forcibly relocated to other schools where the teachers had no kind of link with the community and, therefore, could not present a risk. Around 13\%, also, were subjected to military tribunals, which sometimes handed down the harshest sentence available. Approximately $15 \%$ of teachers took refuge abroad wherever they could - primarily in France, Britain, the Soviet Union, Cuba or Mexico, where they continued experimenting with Freinet techniques, sometimes with great success (Hernández Díaz \& Hernández Huerta, 2009).

\section{Extensions of Freinet schools into the community, and social construction of democracy}

Freinet's was an agenda to radically transform the world through schooling. This was reflected in the ideas and schooling practices, which took on a markedly social nature and made notable inroads into the community. Spanish teachers viewed primary school as an immutable social asset - one of the best means of elevating Spain's level of culture, especially 
in rural areas, many of them isolated and grindingly impoverished, and thereby encourage progress, push the boundaries of freedom, increasing the levels of social justice and forge bonds of solidarity within the community. These considerations meant that the ultimate goals of schooling had to go beyond mere instrumental literacy, or the ideal of the cultured person, and encourage the formation of free, honest and balanced individuals, capable of fully integrating into social and political life, participating in the various public spheres of the community which they serve and which serves them, and conduct themselves as citizens aware of their freedoms, rights and responsibilities. Consequently, the content needed to change, the work needed to be organised differently, and the areas of influence of school needed to expand and be considered differently.

The traditional academic disciplines continued to play a central role, particularly critical reading and accurate writing, as these were considered fundamental skills for social and political participation. However, importance was also attached, and more prominence given within the curriculum, to other subjects and contents which would contribute to this aim, such as art and music, which helped to develop the children's aesthetic dimension, their sensitivity and sense of good taste, proportion and beauty: various types of pleasurable activities which facilitated communication and socialisation of the pupils, and issues relating to good citizenship. Citizenship was taught in the form of standards of behaviour for life in the community; clear and simple concepts about the organisation and operation of a democratic regime - particularly the democratic regime that had been established in Spain on 14 April 1931; comments on and analysis of the political reality in Spain at that time (and sometimes on the international political reality as well); and the study of children's rights. In this respect, particular emphasis was placed on two documents: firstly, the Geneva Convention, explaining its contents to the children and making sure they were aware that, from that moment on, they had become social, political and judicial subjects, enjoying rights and freedoms, and that they constituted a new sociological category, internationally recognised, with their own identity; and secondly, the Spanish Constitution of 1931, and specifically article 43, on children's rights. In that article, in addition to perceiving children as part of the spirit which drove the New School, emphasis was placed on the idea that, to make possible a freer, fairer and more supportive society, they needed good teachers, good material conditions in schools and good and fluid relations between the school and the social environment in which it sat - especially with family:

Every child has the right to have teachers for whom education is their true vocation - teachers of character, full of goodwill; select and illustrious men; paid fairly; who do not view their positions simply as a means of earning a living; who believe in the ideals most difficult to achieve; who are aware of the responsibility they bear for creating social justice; who do not forget that the true teacher is the child, and that humanity is sovereign in all nations. (...) to a simple, attractive, happy and clean school environment, which they themselves will help to beautify and decorate. (...) to have their teachers and their parents work side by side in educating them, for the town and school to work together, as these are the two levers which drive the world, in the hands of the great dreamers.

During the Civil War, civic education continued with the aim of promoting common living under a democratic system, critically analysing the political situation and providing the children with ideas, skills, abilities and basic knowledge for their social and political participation, but with certain added nuances, derived from the teachers' own experience in a civil war which they were beginning to suspect was the precursor to a global conflict. Gradually, 
the defence of the Republican government - and its main ally, the USSR - and the reports, news, personal stories and war reports began to occupy a great amount of space, both physical and academically speaking (Hernández Díaz \& Hernández Huerta, 2010) and, with that, various forms of propaganda began to creep in, the slogans, ways of articulating one's thoughts, and ways of understanding reality. The perception of war which the pupils had, to a large extent, fitted in with the perception fabricated and disseminated by the propaganda machine. On occasion, the empirical proof, the solid evidence of reality and the search for complex explanations were supplanted by the principles of plausibility, emotivity, opportunity and simplicity of the reality. This was reflected, amongst other things, in the language used, which took on a style not unheard of in the class struggle, and certain totalitarian traces. For example, workers became the "proletariat" - a term which lumped together industrial workers, small business owners, crop farmers and livestock farmers - and the Francoist, fascist and Nazi regimes, with no distinction or nuance made between them, were encapsulated by the expression "international fascism", which became a broad and unclear category covering all those countries, groups and individuals who disagreed - or simply did not demonstrate agreement - with the social and political directions taken by the Republic at the elections in February 1936. Thus, to a certain extent, the children were forced to give up on part of their childhoods, reaching premature personal, political and social maturity. A number of children felt an inclination to be "pioneers of the new social revolution, the new constructive revolution", and a majority became fully aware of the sacrifices that their elders were making to ensure their survival, which drove them to try to be socially useful and economically productive in order to take the workload off the adults:

It is at the age of 14 that the idea of leaving school and finding a workshop develops in our brain. As soon as we wake up in the morning, our first thought is to quickly get to work, and thereby support our brothers in arms at the front. However, our attempt was foiled because we had to go back to class as schoolchildren, instead of going to a workshop to work as an apprentice and start earning a living for ourselves. (...) In these times we live in, it is needed more than even, and we need to make sure this happens, to raise Spain up from the ruin that will come from this damned war which we all despise. We should now make forays into the world of work, because in the future, we shall surely have to work harder than our strength allows to rebuild Madrid and, with it, the whole of Spain, which will undoubtedly be destroyed by the fascists and the German legions. With a job, in addition to learning, you feel great satisfaction when you finish it, because you've done something to benefit others. For that reason, we have a very strong desire to go to work, and we would very much appreciate being allowed to, so that our generation is no longer a burden (Revuelta, 1937).

In accordance with the principles of activity and experimentation inherent to Freinet's educational philosophy, teachers managed to offer their students different forms and styles of organising their schoolwork which represented experiments in participative democracy, based on cooperation, collaboration and communication, personal responsibility and solidarity in collective work, also capable of safeguarding the individual and collective rights and freedoms. These experiments required the members of the school community - particularly the students - to employ collective bargaining strategies to resolve tension and settle any differences which might arise, seeking to find consensus solutions supported by a broad majority and respect the rights of the minorities, forcing them to become aware of the complex and multifaceted nature of life in society, and the possibilities and limits of tolerance. Thus, school environments largely became labs in which democracy was formulated and tested. 
On the one hand, the technical innovations made to the school encouraged a more lively, freer and more casual working environment, which facilitated the development of social skills, means of interaction and customs of democratic participation in the community. ${ }^{7}$ Free texts, which were the starting point and the raison d'être of the school printing press, quite literally gave the children freedom: from a very early age, they learned to push past censorship, either from themselves or from others, and to value words as a tool to describe reality; to convey ideas, thoughts and feelings; a strategy for conflict resolution and a tool to take part in public life. The printing press, for its part, involved implementing a clutch of strategies of free, independent, responsible work in solidarity with others, based on the principles of communication, collaboration and cooperation. Thus, for example, self-regulating working teams were set up, having clearly defined roles and responsibilities and ample capacity for action and decision-making, having to work together in a coordinated manner; and, although all free texts were valued and were included in each pupil's personal libro de vida, those chosen for publication in the collective workbook - an expression of the community in the school were submitted to the judgement of all the classmates, who helped, at the same time, to make them more accurate and correct them. Amongst other things, this style of organising life in school encouraged a freer, more informal type of socialisation, a certain distance away from the gaze of the teacher - "their worst enemy" (Benaiges Nogués, 1935a) - and, in concert with the ways in which children related to one another outside of the school and outside their family environment, forced the children to adjust their own attitude, to compare it with that of the others, to discover that their ideas were not the only ones, or even the most correct, and that these opinions only gained meaning, significance and social relevance when they were shared with others, especially in public arenas.

The printing press became something more than a pedagogical tool; it turned into an extension of the school, capable of connecting it with the local environment, and connecting both with broader communities further afield. The libros de vida, which were the final and most visible result of working with the printing press, were distributed among the school children, who took them home, and also, where possible, became points of origin for social, political and cultural activity in the local community. Through the pages of these publications, the local leaders could receive some feedback on their action in the community, and the community as a whole could take a look at portions of itself, its achievements and aspirations, its social, cultural, material and environmental heritage, its ideas and customs. The correspondence emphasised this, meaning that the school and the community of which it was part took on a new dimension: the communication network set up managed to establish contact between the island-schools in the Freinet archipelago in Spain, and contact between those schools abroad - France, Belgium, Switzerland, Bulgaria, Hungary, the USA, Argentina, Mexico, Uruguay and Venezuela - and facilitated the circulation of information, printed texts, ideas, experiments, desires and ways of operating in the world. What the children saw, thought, felt, said and did, and what went on in the town, ceased to be objects of interest solely for themselves, their friends, family and neighbours; they were affairs which could be shared with children and adults in other schools and other places, who, in turn, would correspond with the originators in a similar way. In the majority of cases, for the schools and, by extension, for the communities, this meant the opportunity to open up means of escape from their social and cultural isolation. Every copy received through the school correspondence system multiplied the possibilities available to the readers to access other realities, far removed from their own in terms of distance, where, sometimes, the customs, people, language and urban and natural environments differed from

\footnotetext{
${ }^{7}$ Some discussion of the strictly technical and pedagogical aspects of the school printing press may be found in Hernández Huerta and Sánchez Blanco (2013).
} 
that which they already knew, their daily and familiar routine, to which they would otherwise have difficulty accessing.

An especially representative example of the interest and pedagogical, social and cultural potential of Freinet's system of inter-school correspondence, capable of catapulting the children into strange realities, far removed from their own in every sense, is the experiment carried out in the school Nacional Unitaria de Niños Factoría de los Ángeles de Caminomorisco, a small settlement in Las Hurdes in Extremadura, the poorest region in the whole of Europe for a significant part of the $20^{\text {th }}$ Century. ${ }^{8}$ It was one of those villages which exist quite apart from modern life, in a reduced and endogamic environment, practically cut off from the rest of the world. Maximino Cano Gascón, a teacher and disciple of Freinet, working at a school in La Huerta, a little over two kilometres from Caminomorisco, described the awful conditions in which children in Las Hurdes grew up:

If, when walking across the sun-soaked pasture of Jerte which enhances the beauty of your lovely city, you discern in the distance the precipitous peaks of the dreadful Hurdes sierra, remember that here, among the boring brush and the rough slates of this barren land, the breeding ground of poverty and pain, live several hundred children who have no shoes, and are poorly clothed; many of them - most of them, even - go hungry, and have never seen a motorway, an aeroplane, a cinema, or a radio... they do not even have toys. In fact, they barely play at all, because, after class time and during public holidays, they have to work as though they were full-grown adults in the arduous tilling of a thankless land! (Maestro, 1933).

There, in Caminomorisco, between 1932 and 1934, in that harsh, hostile and isolated environment, the pupils published the libro de vida Ideas y Hechos (Ideas and Facts), which was exchanged with fifteen publications from eight different provinces of Spain (Lérida, Mallorca, Barcelona, Soria, Huesca, Cáceres, Toledo and Pontevedra) and with another six abroad (France, Belgium, Andorra, Mexico and Uruguay). This broad communication network was also a tool to publicise the work carried out by the teacher and the pupils in school, which was echoed by both the CEL and the CETF: 1935 saw the publication of Vida Hurdana (Life in the Hurdes) which offered an overview of the culture, customs and games of the region - it included a short glossary of expressions - and was the second edition in the collection Lo que escriben los niños; and a selection of works from Ideas y Hechos were translated into French and published as Les Hurdes, which was issue 78 of the collection Enfantines (VV.AA, 19321934, 1935, 1936).

The impact of the technical innovations was also felt in the community in a different way, altering the relations between educational institutions and the schooling industry. That industry still had a presence, but played less of an important role, reduced largely to specialist didactic tools, basic elements of school equipment and reference books or consultation books, which became less central. However, the new daily schooling practices also required specially designed materials, from the printing presses themselves to the gouges used to work on the linoleum. This meant that teachers had to employ various strategies to construct, distribute and acquire these materials. The result was alternative business formulas, new relations with the local institutions and economic or labour practices which encouraged the development of the community. Thus, the cooperative established advantageous agreements with large local

\footnotetext{
${ }^{8}$ The studies conducted by Antonio García Madrid $(2009,2013)$ are a good source on Freinet's influences in Las Hurdes in Extremadura.
} 
industries (Hernández Huerta \& Sánchez Blanco, 2013), such as the typography casting firm Neufville in Barcelona, and with well-known brands of manufacturers of school materials, such as Kaspar and Soennecken, and acted as a distributor for those products, both for members and non-members, although non-members had to pay a premium. It facilitated access to the press offered by the CEL, to Neufville's printing blocks, the watercolours made by Kaspar and nib pens from Soennecken, and supplied ink cartridges of different colours, ink rollers, boxes, setting sticks, gouges, linoleum and paper. Other economic dynamics were set up which benefitted greatly from the development of small businesses and local artisans. This was possible thanks to the aforementioned publications of Revista de Pedagogía, which allowed teachers to set out an exact list of materials that needed to be bought, for the most skilled printers, who built their own presses without the need for imported materials (be they from other regions of Spain or from abroad), and for the less skilled as well, who could rely on the participation of carpenters and/or smiths. In certain cases, regardless of how the materials were acquired, the teachers had cooperation from the local authorities, who contributed financially to the buying of the press and the basic materials to work with it.

On the other hand, as far as possible, the social and academic life of the school was constructed in accordance with the principles of free work, spontaneous cooperation, social participation and community responsibility. This gave rise to organisational experiments which made the children the protagonists in their own education, giving them a certain degree of autonomy and freedom to decide on some points of daily routine, and fomenting democratic lifestyles based on communication, collaboration and self-regulation. Assemblies were one of the most commonplace strategies that were used to manage coexistence, to establish the standards which would guide the children's lives together, and organise a portion of the time, space and focus of the schoolwork. Encouragement was also given to sociocultural initiatives, which had the ability to take action - mainly school libraries which, on some occasions, extended their range of activities and opened up their spaces and services to the rest of the educational community. However, the greatest emphasis was on promoting various forms of child associationism - mainly school cooperatives - as they gave the children "(...) the opportunity to organise freely, to validate their individual and collective initiatives, to improve their working conditions on their own, and consciously contribute to the school's activity, both within its walls and without them" (Redacción, 1936d). Children's republics were variants of the associationism which facilitated radical experiments in the social construction of democracy through the school. Such republics manifested themselves in different ways, but in all cases, they involved ample capacity for self-management and self-regulation, participation and commitment on the part of the various members of the school community - teachers, families and non-teaching staff - and collaboration of numerous social actors in the local area. Whatever the form of organisation and construction of community life which the residents of schools decided to adopt, thanks to their activities, associations, cooperatives and children's republics became key elements for the cultural dynamisation of educational centres and, on occasion, also for their material and pedagogical progress, managing to organise fundraising campaigns to buy a printing press for the school and covering a portion of those costs or the costs relating to its running.

The idea of connecting the school with real life consisted not only of allowing real life to infiltrate the school environment, but also of trying to eliminate the physical and symbolic boundaries between the two, so that the school managed to project into and leave its mark on the community around it. Indeed, the novel teaching techniques enabled more lively and dynamic educational styles to be put into practice, and meant that existence beyond the four walls of the school found a place in daily life, thanks mainly to free texts, which, in addition to strictly pedagogical aspects and aspects relating to the children's lives, infused elements of popular culture, of day-to-day life in the family and outside of it - extraordinary events which 
produced a certain impact among the neighbours, and an endless stream of further issues (Hernández Huerta, 2012a). However, the goals of Freinet's approach to modernise the schooling system and build a freer, fairer and more supportive world through education meant extending the radius of action of the school itself, reaching out into the community, considering the local municipality to be one more area of the school environment, and its residents to be actors with a crucial role to play in the children's educational framework.

Family was one of the areas of the community over which schools extended their influence, managing to establish relations of mutual collaboration and cooperation. The teachers were convinced that the school's educational agenda should also be continued, as consistently as possible, outside of class, and outside of school hours. For this reason, they sought the cooperation of the children's families in a number of ways. Firstly, they opened up channels of communication through which, with the aim of enriching and orientating the families' educational activities, they offered parents various types of advice which helped those parents realise their responsibility for socialising their children, helped them understand the condition and situation of children and encouraged democratic lifestyles. Secondly, they encouraged families to get involved in schools, through associations of friends of the school or through parents' groups, which became focal points of activity and dynamisation of cultural and academic life and enjoyment in schools; mediators and pressure groups to call for greater and better attention for the schools from the local authorities; and, on occasions, promotors of the Modern School techniques, providing financial resources to buy a school printing press and the rest of the necessary materials.

A representative example of these experiments aimed at bringing families and schools closer together was that which took place in the national graded children's school in Menarguens (Lérida). The final page of the school newspaper Inquietud, published during 1935 and 1936, was a space reserved for teachers, and was used to give recommendations and educational considerations to the families, through short, clear texts. ${ }^{9}$ Through these pages, they made the point that lack of punctuality and absenteeism were among the leading causes of failure in school, appealing to the responsibility that families had for their children's attendance at school, and warning them that shirking this responsibility could harm the children and prevent the teachers from doing their jobs properly. They emphasised the importance of the adults' lives in the educational process - particularly of mothers and fathers, close family members and teachers, as these people formed a large part of the points of reference which the children had to learn how to participate in community life. They also recommended that fear should not be used as a teaching strategy, suggesting instead that it be replaced by styles based on calm, tranquil argumentation, managing to reason with the children, explain things, helping them to understand the circumstances, encouraging the children to be gallant, and leading them to gradually learn to deal with life, whilst obviously respecting the needs, possibilities and limitations that age brought with it. They advised families, in order to achieve a brighter future, to foster love of truth and honesty in the children - these were considered key values for liberal democracies -, always treating them with honesty, without tricks or ruses to break their will, modify their behaviour or avoid issues that were controversial or uncomfortable for the adults.

Thus, the teachers at the Menarguens school requested and encouraged active participation in school life by the children's families, resulting in the formation of an Association of Friends of the School. The draft Statutes were published in Inquietud, in the editions corresponding to April and May 1935, with the aim that all parties which would be involved in the aforementioned Association could give their views on the subject, proposing modifications or amendments where necessary. The process was quick, and on 4 June that year,

\footnotetext{
${ }^{9}$ The facsimile edition of this collection, and a previous study of the documentation and the local context of its production, can be found in Marqués and Reguant (2010).
} 
the Association was formally established, with the following aims: to safeguard good quality in the school's installations; organise soirées, conferences and excursions; contribute to the overhaul of the school's equipment; work with a number of other bodies involved in the school's social achievements; cooperate with the teachers in their work; and, as far as possible, be responsible for progress in the town and progress by its residents. All the teachers in the school group would be full members of this body, and the pupils' parents and their legal representatives would also have the right to join the association. The Governing Council, which would meet every two months during the school year, would be made up of a President, a Secretary, a Treasurer and two Spokespersons.

In their attempt to open up the school institution to the stimuli of the outside world, the teachers made the urban spaces and natural environments in their towns into part of the school scenery; and all its constitutive elements - human, material, cultural and environmental - could be used as educational stimuli. This manifested itself in different ways. First of all, it materialised in the form of excursions to parks, woodland, fields, rivers and seaside near to the children's town or neighbourhood, depending on the dimensions and type of the population, and educational visits and walks to local points of interest, factories, workshops, official organisations, schools and museums of varying types. These activities had obvious educational value, as they were always accompanied by scientific explanations and, where possible, direct experimentation. However, they also opened the door to broader educational possibilities for the children and for the projection of the school into the community. Thus, the walks, visits and excursions served to raise the profile, among the local community, of some of the work behind done by the teachers and students; to establish contact with other forms of education; to see, hear and touch what was being done, said and produced in the local area; to explore spaces of collective memory; to discover their community's social, cultural and material heritage; to become aware of the institutions and make direct contact with the major players in public life in the area; when such direct contact was possible, the activity took on a new significance, becoming what was probably the children's first ever, fleeting and minimal, experience of civil participation, and with it, the feeling of being recognised as subjects under the law.

In this respect, the case of the Freinet School in Tibidabo (Barcelona), founded in 1937, may be seen as an elucidating example. ${ }^{10}$ The teachers and students, mainly orphans or refugees fleeing from the fighting on the front line, took many excursions to nearby natural settings; they went many times to visit the Dalton Plan School to see their installations and take part in cultural activities. Yet the most numerous and most exciting visits were those to centres of political interest, which gave them the opportunity to personally meet notable figures in political life in Spain at the time. Three such visits are particularly worthy of note, all of them taken in December 1937: 1) they went to the Embassy of the USSR in Barcelona for an audience with the diplomat, deliver to him a number of issues of their school newspaper, Tibidabo, and try to convince him to allow them to begin corresponding with children from the Soviet Union and with other Spanish children who had been evacuated; 2) having learnt that the Mayor of Madrid was visiting Barcelona for a few days, they went to see him, were given an audience, and gave him several issues of Tibidabo; 3) a number of pupils, accompanied by a teacher, went to the Ministerio de Instruction Pública (Ministry of Public Education) to meet with the Director General de Primera Enseñanza (Head of Primary Schooling) and, as before, give him a number of copies of their school newspaper (VV.AA, 1937-1938b).

\footnotetext{
${ }^{10}$ An interesting study about this school is that done by Jiménez Mier y Terán (2017), although it does not refer to previous studies which have specifically looked at the question, and even have a facsimile edition of the Freinet-type newspapers published there (Hernández Díaz \& Hernández Huerta, 2010; Hernández Huerta \& Hernández Díaz, 2012).
} 
On the other hand, the exploratory activities were not limited only to the immediate environment. Trips were also taken to places further afield, and school camps/colonies were set up at remote sites, sometimes hundreds of kilometres away from anywhere, with the aim being to expand the students' horizons in life. These activities involved undertaking genuine adventures which, on most occasions, brought totally new experiences for the children, from riding a train for the first time, seeing the sea, or climbing a mountain, to enjoying free time in unfamiliar surroundings, living together in an intense environment, for several days, far from the security of their families, with others like themselves and the teachers responsible, discovering variations from their own culture or taking on responsibilities to ensure the wellbeing of the group. This gave the schoolchildren a view of the world which was fuller and more advanced, but at the same time, more relative, given that, through these practices, their perspectives of reality were expanded and multiplied and, inevitably, their own existence had to be thought of in relation to that of others, despite the disagreements which could result from that coexistence.

Finally, Freinetian schools tended, tentatively and gradually, to turn into cultural points of reference for the local area, mediators of community development and institutions of social protection of children. The teachers sought the economic cooperation of the local authorities to improve the school equipment, mainly to buy school printing presses and printing materials, and they managed to establish agreements with those institutions to provide certain services to the school, including transport in large cities like Madrid and Barcelona, where the pupils enjoyed substantial fare reductions on the tram lines that stopped near to the schools. In addition, outside of class time, they organised adult education classes, either to provide the adults with basic literacy skills, or to offer continuing professional development, mainly to crop farmers. A number of permanent services offered by the schools were made available to the community, such as school libraries, which set up systems of lending books to pupils' family members and neighbours in the town or area. Thus, a portion of the activities conducted by student associations, children's cooperatives, associations of friends of the school or parents, and groups of former students, benefited from a certain degree of social projection. There were literary soirées, works of theatre and lecture series that were open to the whole of the school community and to neighbours and authorities in the area, along with friends and colleagues from other schools. Occasionally, these events also enjoyed collaboration and even direct involvement from various educational and social actors - families, public organisations, private entities, associations and so on - involving the use of other public spaces in the locale other than the school - theatres, cinemas, plazas, athenaeums, etc. In some cases, the schools, through their cooperatives, carried out work for the benefit of the community, and even became elements in the relative economic upturn of the area.

During the Civil War, the social nature and the sense of community service in schools were more intensely felt, due to the emergencies, harshness and necessities imposed by the civil conflict, but also because of the sensitivity and commitment of teachers and the educational administrative authorities. Some schools began to operate as boarding schools, and became centres of refuge for children who had been orphaned or had been evacuated from towns near to the front, mainly in Aragón and Madrid, where their lives were at greater risk, owing to the constant and indiscriminate bombardment. They also served as a vital and professional refuge for teachers who had fled their homes, taken by surprise by the outbreak of war, or who had had to flee, persecuted by the Francoist forces. This situation, owing to the harsh circumstances, the daily living with the threat of annihilation, the personal dramas which the children and adults brought with them, the shared sense of fighting for a freer and fairer future, and the sense of camaraderie that created, brought about the possibility of forging new bonds of brotherhood - and strengthening those already in existence - between children in the various regions of Spain, and stirred up feelings and attitudes of solidarity in the residents - children and adults - 
and the authorities in the host community, who gave the refugees homes, food and clothing, and to as full an extent as possible, managed to safeguard the children's childhood. The point was made thus, for example, in an open letter from a child from Aragón to Catalan children, published in the school newspaper Germanor, published by the school group of the same name in Olot (Girona):

Because of the war, we had to leave our town, Gelsa, leaving our parents deeply saddened and taking refuge in Catalonia. (...) Here, we are very happy, because we are well loved, we lack nothing and, in spite of the language barrier, Catalan children act like our brothers and sisters, making an effort to make themselves understood, and we respond to their kindness by learning to talk to them in Catalan (...). Ultimately, we are writing this to express our gratitude to all those who have contributed to making us happy, recognising that this war, which has caused so much pain and sufferance, will at least have had the good consequence of forging a strong bond between the children of Catalonia and those of Aragón and other regions" (Garcés \& Loras, 1937).

An especially significant experience along these lines was that which took place in the permanent school colony run by Barcelona City Council, known as the Martorelles Children's Republic, which operated, as a boarding school, during the Civil War. The population was made up of children from different regions, but mainly Catalonia, and teachers who had also been exiled: among them, Simeón Omella, one of the oldest and most prominent members of the CETF. There, life at school ran in purely Freinetian style: the working day was full time, and work was organised around the school printing press, resulting in the libro de vida entitled La Font; the school welcomed various kinds of guests, went on excursions and educational walks, held festivities and cultural activities open to the general public, and matters that were of interest to the community were regulated and managed through assembly-based systems and a children's cooperative. ${ }^{11}$ Yet what it is really interesting to point out, here, are two aspects of life in the colony which offer a good indication of the degree of self-management and the measure of social projection that Freinet schools managed to achieve, and which made the experience rather unique. Firstly, the material and spatial conditions in the colony offered its residents independence and the option of carrying out other types of financially profitable activity. In addition to a swimming pool and the building which housed the school, the colony had a pigeon loft, a number of workshops equipped with professional tools, a farm with rabbits, chickens, ducks and pigs, and several crop fields with fruit trees and vegetable gardens. These resources were managed by the children's cooperative, which was in charge of tending the crops and the animals, organising work in the workshops to build basic necessities and sell any surplus, either directly or in the market in town; the money from these sales, in turn, served to buy items which could not be produced in the colony itself - clothes, processed foods and building materials - and any surplus was divided between the children's families. Secondly, the teachers and the colonists, in order to obtain extra financial resources for the survival of the settlement, took advantage of the work opportunities available to them in the surrounding area - for example, participating in wine harvesting and clearing of the lower slopes undertaken by the locals and the civil authorities during the spring and part of the summer of 1938 (VV.AA, 1937-1938a).

${ }^{11}$ With regard to Simeón Omella's life and career, readers could usefully consult the work of Sebastián Gertrúdix Romero de Ávila (2002) and Jiménez Mier y Terán (2007b). A detailed description of typically Freinet activities at the Martorelles colony can be found in Hernández Huerta (2012b). 


\section{Conclusions}

In its infancy, the Freinet movement in Spain developed on two different levels. The first, more widespread, which built the movement's general background framework and lasted up until the end of the Civil War, operated on the basis of the principles of communication, collaboration and cooperation, but in a way that was free, casual, fluid, spontaneous, and organised into small cells or lone "sharpshooters". The second level, which was more visible although notably smaller in scale, was carried out by the CETF: the major effort to bring together and coordinate between these informal networks of solidarity and mutual understanding, on the part of the movement's charismatic and symbolic leaders. From the very beginning, life in the organisation happened in various styles of participative democracy and collective bargaining, resulting in the group's practices of assembly, a set of collegiate bodies - councils, committees and advisers - working together in a coordinated manner, and the open nature of the project itself. What was absolutely clear in the teachers' minds was that they wanted to change the world with words, through the schooling system; the rest was a tenuous web of desires for an uncertain future, which would have to be untangled and rewoven collectively. This allowed various types of dilemmas to arise within the group; some, such as the issue of inter-school correspondence - where the two opposing factions called for security and for liberty - affected the substance of the organisation and could have influenced the possible trajectories it could take.

The CETF's most ambitious projects, such as the creation of the general school file, organisation of school correspondence, sale of materials, collection of books by children for children, publishing of the journal and organising of conferences, required active participation and commitment from a great many members, and significant efforts in terms of communication, collaboration and cooperation with one another and with other social actors (public institutions or private enterprises). These activities gave teachers a certain sense of belonging to a group made up of others like them, with shared concerns, similar interests and common goals: to modernise the schooling system, to bring education to life, and to help make the world a fairer, freer and more supportive place. The journal and the conferences became spaces for meeting - be it physically or symbolically - to reflect on matters, exchange ideas and compare technical/professional criteria, which helped to define the group's agenda, to grow that sense of belonging and develop an alternative collective identity, whose deepest and most radical meaning and significance lay in its markedly popular and democratic nature popular, and the plainly socio-community-based projection. Furthermore, the conferences helped bind the group together by establishment links and direct personal connections, and they represented experiments in the social building of democracy.

The introduction of the printing press into classrooms represented something more than a technical innovation that could modernise the teaching system. It became one of the main extensions into the community on the part of Freinet schools. To begin with, it was clearly and directly an extension, thanks to the tool of free texts, which meant that the world around the children was brought into the classroom, and to inter-school correspondence, which projected the life of the school and the community to which it belonged into other, wider communities, managing to incorporate them, sometimes, to form global networks of communication, construction of social ways of thinking (Taylor, 2006) and extension of collective memories (Halbwachs, 2004). Secondly, it was also an indirect extension, whose results were especially perceptible in the community in the medium term, through the strategies implemented to organise work with the printing press. These strategies went beyond the idea of an enlightened, cosmopolitan citizen, instilling in the pupils a democratic way of life, based on self-regulation and direct participation in the processes of collective bargaining - approaches which, gradually, would filter through into other social areas of action. This process was aided, in the same way 
- slow and gradual, by social infiltration, but with greater visibility in the community - by cooperatives, associations and children's republics - all examples of different versions of selfgovernment and self-management, which gave the children what was probably their first experience of social construction of democracy in formal environments.

Finally, the culture of Freinet's ideas implemented in Spain developed additional extensions into the local communities where the schools were based. Some of these excursions, walks and camps, associations of the parents of pupils, hosting of guests, organisation of cultural activities and services open to the residents of the township, trade links and, very occasionally, work done for the community - generate immediate visibility, and produced a direct social impact. In addition to helping connect life in the classroom to what was going on outside it, they helped to set the school up as one of the socio-cultural reference points, leading the teachers and children to be considered agents of local development, and the town to be thought of as merely another area of the school, whose resources and stimuli could become part of the daily educational repertoire.

\section{References}

Almendros, H. (1932a). La correspondencia escolar. Revista de Pedagogía, (126), 243-253.

Almendros, H. (1932b). La imprenta en la escuela. Revista de Pedagogía, (128), 369-370.

Almendros, H. (1932c). La imprenta en la escuela. Revista de Pedagogía, (130), 448-453.

Almendros, H. (1932d). La Imprenta en la Escuela. La técnica Freinet. Madrid: Revista de Pedagogía.

Almendros, H. (1933). Técnicas auxiliares de la escuela. El cinema, la radio, los discos. Revista de Pedagogía, (133), 19-24.

Almendros, H. (1936). Intercambio de impresos. Colaboración, la Imprenta en la Escuela, (11), 110-112.

Benaiges Nogués, A. (1935a). Azul y rojo. La imprenta en la escuela. Colaboración, la Imprenta en la Escuela, (4), 29-32.

Benaiges Nogués, A. (1935b). Intercambio de impresos. Colaboración, la Imprenta en la Escuela, (9), 90-91.

Bover Oliveras, L. G. (1935). El Congreso de Lérida. Colaboración, la Imprenta en la Escuela, (2), 12-14.

Cid Fernández, X. M., Carrera Fernández, M. V., Diéguez Sans, N., \& Cid Rodríguez, A. (2017). Educació per a la pau en la trajectòria freinetiana. Del seu discurs originari als actuals moviments de l'escola moderna a la península Ibèrica. Educació i Història: Revista d'Història de l'Educació, (29), 41-63.

Cluet, M. J. (1929a). La educación nueva en la práctica. La imprenta en la escuela. Revista de Pedagogía, (89), 203-208.

Cluet, M. J. (1929b). Manera de construir el modelo de 1928 de la prensa escolar Freinet. Revista de Pedagogía, (91), 320-322. 
Cluet, M. J. (1933). La imprenta en la escuela. La última prensa. Revista de Pedagogía, 102108.

Cozcolluela, T. (1935). El Congreso de Huesca. Colaboración, la Imprenta en la Escuela, (6), 45-47.

Escolano Benito, A. (2002). La educación en la España contemporánea. Políticas educativas, escolarización y culturas pedagógicas. Madrid: Editorial Biblioteca Nueva.

Ferraz Lorenzo, M. (2017). La segunda época de cooperación, experimentación y aplicación de las técnicas Freinet en las Islas Canarias (1977-1982). Educació i Història: Revista d'Història de l'Educació, (29), 151-170.

Freinet, C. (1936). Nueva vida escolar. Colaboración, la Imprenta en la Escuela, (14), 145146.

Freinet, E. (1983). Nacimiento de una pedagogía popular. Historia de la Escuela Moderna. Barcelona: Laia.

Garcés, E., \& Loras, B. (1937). Los niños de Aragón a los de Cataluña. Germanor, (1), s/p.

García Madrid, A. (2009). Un ejército de maestros. Experiencias de las técnicas de Freinet en Castilla y Extremadura (1932-1936). Salamanca: Universidad Pontificia de Salamanca.

García Madrid, A. (2013). La revista escolar "Sementera" de la graduada $\mathrm{n}^{\circ} 1$ de Plasencia (Cáceres). Papeles salmantinos de educación, (17), 49.

Gertrúdix Romero de Ávila, S. (2002). Simeón Omella: el Maestro de Plasencia del Monte. Zaragoza: Diputación General de Aragón y Caja Inmaculada.

González Monteagudo, J. (1988). La pedagogía de Célestin Freinet: contexto, bases teóricas, influencia. Madrid: Centro de Publicaciones. Secretaría General Técnica.

González Monteagudo, J. (2013). Célestin Freinet, la escritura en libertad y el periódico escolar: un modelo de innovación educativa en la primera mitad del siglo 20. História da Educação, 17(40), 11-26.

Groves, T. (2002). The Teacher as an Agent of Alternative Culture: The Teachers' Movement during the Transition to Democracy in Spain (Salamanca, 1970-1979). Tel Aviv University, Tel Aviv.

Groves, T. (2009). ¿Qué significa vivir en democracia? La movilización sindical de los maestros durante la Transición Española. In R. Quirosa-Cheyrouze Muñoz \& M. Fernández Amador (eds.), Sociedad y movimientos sociales (pp. 203-218). Almería: Instituto de Estudios Almerienses, Diputación de Almería.

Groves, T. (2010). ¿Qué engaña más, la memoria o los documentos? Experiencias de la pedagogía Freinet en la escuela rural en los años setenta. Foro de Educación, 8(12), 171-173.

Groves, T. (2012). Everyday Struggles against Franco's Authoritarian Legacy: Pedagogical Social Movements and Democracy in Spain. Journal of Social History, 46(2), 305-334. 
Groves, T. (2014a). Political Transition and Democratic Teachers: Negotiating Citizenship in the Spanish Education System. European History Quarterly, 44(2), 263-292.

Groves, T. (2014b). Teachers and the Struggle for Democracy in Spain, 1970-1985. New York: Palgrave Macmillan.

Groves, T. (2017). Freinet y los maestros españoles: la configuración de un movimiento social y pedagógico (1969-1983). Educació i Història: Revista d'Història de l'Educació, (30), 133154.

Halbwachs, M. (2004). La memoria colectiva. Zaragoza: Prensas Universitarias de Zaragoza.

Hernández Díaz, J. M. (2008). Utopía y realidad de las prácticas escolares renovadoras en España (1900-1939). In V. Juan (Ed.), Museos pedagógicos: la memoria recuperada : Museo Pedagógico de Aragón, Huesca, octubre 2008 (pp. 135-156). Huesca: Gobierno de Aragón, Museo Pedagógico de Aragón.

Hernández Díaz, J. M., \& Hernández Huerta, J. L. (2009). La represión franquista de los maestros freinetianos. Aula. Revista de Pedagogía de la Universidad de Salamanca, (15), 201227.

Hernández Díaz, J. M., \& Hernández Huerta, J. L. (2010). Cuadernos escolares y técnicas Freinet en España durante la Guerra Civil (1936-1939). In J. Meda, D. Montino \& R. Sani (eds.), School exercise books. A Complex Source for History of the Approach to Schooling and Education in the 19th and 20th Centuries (pp. 769-792). Macerata: Edizione Polistampa.

Hernández Huerta, J. L. (2012a). Freinet en España (1926-1939). Escuela popular, historia y pedagogía. Valladolid: Castilla Ediciones.

Hernández Huerta, J. L. (2012b). Simeón Omella Ciprián. Notas Biográficas y realizaciones freinetianas. In F. Zurriaga (Ed.), Pàgines vives. Quaderns Freinet. Les revistes escolars de la Segona República. Castelló de la Plana: Universitat Jaume I.

Hernández Huerta, J. L. (2017). Influence and Reception of Freinet in Spain. Map of the Historiographical Maze: Possible Means of Escape (1979-2016). Educació i història: Revista d'història de l'educació, (29), 221-246.

Hernández Huerta, J. L., \& Hernández Díaz, J. M. (2012). Freinet en España (1926-1939). História da Educação, 16(36), 147-161.

Hernández Huerta, J. L., \& Sánchez Blanco, L. (2013). Ideas, materiales y prácticas Freinet en España durante la II República. Innovación Educativa, (23), 75-95.

Jaume i Campaner, M. (2017). Tres assajos d'aplicació de les tècniques Freinet a Mallorca per iniciativa del mestre Teodor Terrés Lladó entre 1933 i 1937. Educació i Història: Revista d'Història de l'Educació, (29), 65-97.

Jiménez Mier y Terán, F. (1996). Freinet en España. La revista Colaboración. Barcelona: EUB.

Jiménez Mier y Terán, F. (2007a). Batec. Historia de vida de un grupo de maestros. Lérida: Universitat de Lleida. 
Jiménez Mier y Terán, F. (2007b). El libro de los escolares de Plasencia del Monte. Zaragoza: Gobierno de Aragón. Departamento de Educación, Cultura y Deporte. Museo Pedagógico de Aragón.

Jiménez Mier y Terán, F. (2012). Nacimiento y víspera de la Cooperativa. In F. Zurriaga (Ed.), Pàgines vives. Quaderns Freinet. Les revistes escolars de la Segona República (pp. 133-160). Castellón: Universitat Jaume I.

Jiménez Mier y Terán, F. (2017). La Escuela Freinet de Barcelona. Educació i Història: Revista d'Història de l'Educació, (29), 99-123.

Maestro, E. (1933). A los niños de la Escuela Graduada de Plasencia (Cáceres). Niños, pájaros y flores, (2), s/p.

Marqués, S., \& Reguant, M. (2010). Un poble, una escola, una revista. La revista Inquietud de l'escola de Me nàrguens, 1935-1936. Lérida: Ajuntament de Menàrguens i Pagès Editors S.L.

McLuhan, M. (1996). Comprender los medios de comunicación. Las extensiones del ser humano. Barcelona: Paidós.

Pérez Galán, M. (2011). La enseñanza en la Segunda República. Madrid: Biblioteca Nueva.

Portier, H. (2014). Pionniers du Mouvement Freinet (de l'entre-deux-guerres). Retrieved April 9, 2018 http://www.icem-freinet.fr/archives/divers/pionniers.htm

Pozo Andrés, M. d. M. d. (2003). La Escuela Nueva en España: crónica y semblanza de un mito. Historia de la educación: Revista interuniversitaria, (22), 317-346.

Ramos, A. J. (2017). La revista Escola, òrgan del freinetisme valencià (1965-1969). Educació i Història: Revista d'Història de l'Educació, (29), 125-150.

Redacción. (1935a). Exposición. Colaboración, la Imprenta en la Escuela, (4), 38.

Redacción. (1935b). II Congreso de la Imprenta en la Escuela y Asamblea general de la Cooperativa española de la Técnica Freinet. Colaboración, la Imprenta en la Escuela, (4), s/p.

Redacción. (1935c). La correspondencia interescolar. Colaboración, la Imprenta en la Escuela, (7), 59-60.

Redacción. (1935d). Para los compañeros accionistas. Colaboración, la Imprenta en la Escuela, (5), 38 .

Redacción. (1935e). Propósitos. Colaboración, la Imprenta en la Escuela, (1), 1-3.

Redacción. (1935f). Reunión del Consejo de Administración de la Cooperativa. Colaboración, la Imprenta en la Escuela, (3), 20.

Redacción. (1936a). Colaboración, la Imprenta en la Escuela, (15), s/p.

Redacción. (1936b). Colaboración, la Imprenta en la Escuela, (14), 149-152.

Redacción. (1936c). Colaboración, la Imprenta en la Escuela, (13), 137. 
Redacción. (1936d). Formad cooperativas escolares. Colaboración, la Imprenta en la Escuela, (12), 117.

Redacción. (1936e). Para los compañeros accionistas. Colaboración, la Imprenta en la Escuela, (15), s/p.

Revuelta, F. (1937). Por una España mejor. Renacer, (1), s/p.

Sala Sureda, C., \& Vilaplana, E. (2017). La recuperació de la pedagogia Freinet a Catalunya (apunts de memòries personals). Educació i Història: Revista d'Història de l'Educació, (29), 173-200.

Taylor, C. (2006). Imaginarios sociales modernos. Barcelona: Paidós.

Viñao Frago, A. (2007). Reformas e innovaciones educativas en la España del primer tercio del siglo XX. La JAE como pretexto. Revista de Educación, (extraordinario), 21-44.

VV.AA. (1932-1934). Ideas y Hechos. Escuela Nacional Unitaria de niños Factoría de los Ángeles de Caminomorisco (Cáceres).

VV.AA. (1935). Vida Hurdana. Lo que escriben los niños.

VV.AA. (1936). Les Hurdes. Enfantines.

VV.AA. (1937-1938a). La Font. Periódico escolar. Archivo Histórico de la Ciudad de Barcelona (Barcelona, España), República Infantil de Martorelles (Barcelona, España).

VV.AA. (1937-1938b). Tibidabo. Periódico escolar. Archivo Histórico de la Ciudad de Barcelona (Barcelona, España), Escuela Freinet de Barcelona (España).

Zurriaga i Agustí, F. (2017). Parlem de la formació permanent de l'ofici de mestre i de les idees del Moviment Freinet. Educació i Història: Revista d'Història de l'Educació, (29), 201-218. 